\title{
Dissolving Pulp dari Kayu dan Nonkayu: Tinjauan Proses Pembuatan dan Karakteristiknya
}

\author{
Reynaldo Biantoro ${ }^{1 *}$, Krisna Septiningrum² ${ }^{2}$ Teddy Kardiansyah ${ }^{1}$ \\ ${ }^{1}$ Balai Besar Pulp dan Kertas, Jl. Raya Dayeuhkolot No. 132, Bandung, Indonesia \\ ${ }^{2}$ Balai Besar Industri Agro, Jl. Ir. H. Juanda No. 11, Bogor, Indonesia
}

Diterima : 15 April 2020, Revisi akhir : 10 Juni 2020, Disetujui terbit : 30 Juni 2020

\section{Dissolving Pulp from Wood and Nonwood: Review of The Manufacturing Process and Its Characteristics}

\begin{abstract}
Commercially, about $85-88 \%$ of dissolving pulp production is obtained through the conventional prehydrolysis kraft (PHK) process or sulfite process, complementing other well-known methods such as the bisulfite method and the sulfite-soda method. Currently, the production of dissolving pulp is directed at utilizing abundant nonwood raw materials using environmentally friendly methods. This manuscript discusses the sources of wood and non-wood raw materials, as well as conventional and alternative methods of making dissolving pulp. The process of making dissolving pulp from wood uses a pre-hydrolysis kraft process, while nonwood can use a pre-hydrolysis kraft process or a pre-hydrolysis soda process. The general pre-hydrolysis process can use water or dilute acid. Dissolving pulp from bagasse, banana stalks, bamboo and jute has alpha cellulose content above 90\%, so it can be considered as an alternative raw material besides wood. An alternative method of making dissolving pulp that can be developed is the conversion of paper pulp to dissolving pulp.
\end{abstract}

Keywords: dissolving pulp, prehydrolysis kraft, enzyme, paper-grade pulp conversion

\begin{abstract}
Abstrak
Secara komersial, sekitar $85-88 \%$ produksi dissolving pulp diperoleh melalui proses konvensional prahidrolisis kraft (PHK) ataupun proses asam sulfit, melengkapi metode lainnya yang telah dikenal seperti metode bisulfit dan metode sulfit-soda. Saat ini pembuatan dissolving pulp diarahkan untuk memanfaatkan bahan baku nonkayu yang cukup melimpah dengan menggunakan metode ramah lingkungan. Makalah ini membahas mengenai sumber bahan baku kayu dan nonkayu, serta metode pembuatan dissolving pulp secara konvensional maupun metode alternatif. Proses pembuatan dissolving pulp dari kayu menggunakan proses prahidrolisis kraft, sedangkan dari nonkayu dapat menggunakan proses prahidrolisis kraft atau proses prahidrolisis soda. Proses prahidrolisis secara umum dapat menggunakan air atau asam encer. Dissolving pulp dari bagas, batang pisang, bambu dan jute memiliki kandungan selulosa alfa di atas 90\%, sehingga dapat dipertimbangkan sebagai bahan baku alternatif selain kayu. Metode alternatif pembuatan dissolving pulp yang dapat dikembangkan yaitu konversi pulp kertas menjadi dissolving pulp.
\end{abstract}

Kata kunci: dissolving pulp, prahidrolisis kraft, enzim, konversi pulp kertas 


\section{Pendahuluan}

Pasar dissolving pulp dalam sepuluh tahun terakhir mengalami peningkatan signifikan, diantaranya didorong oleh permintaan yang besar terhadap serat selulosa untuk tekstil (Jarriault et al., 2014). Pertumbuhan ekonomi dan populasi adalah faktor utama pendorong tingginya kebutuhan terhadap produk tekstil. Kebutuhan serat tekstil diproyeksikan akan meningkat dari 72,5 juta ton pada tahun 2010 menjadi 133,5 juta ton pada tahun 2030 (Hämmerle, 2011). Penurunan produksi kapas, keterbatasan sumber daya fosil, isu-isu lingkungan, diperolehnya karakteristik serat selulosa yang lebih baik dari serat sintetik (seperti poliester dan poliamida), telah semakin mendorong perkembangan pembuatan serat selulosa teregenerasi (misalnya viskosa dan lyocell) dari sumber daya hutan (kayu maupun nonkayu) yang dapat diperbaharui (Sixta et al., 2013). Peningkatan permintaan serat selulosa murni juga terjadi pada industri lainnya, seperti bidang medis dan kesehatan, aditif, dan plastik, dengan demikian kebutuhan dissolving pulp sebagai bahan baku juga ikut meningkat (Li, Sevastyanova and Ek, 2012; Jarriault et al., 2014). Dissolving pulp sebagai bahan baku industri derivat selulosa harus memiliki sifat khusus yaitu derajat cerah yang tinggi, derajat polimerisasi rendah dan distribusi berat molekul yang seragam (Hon and Shiraishi, 2001), memiliki kandungan selulosa yang tinggi (90-99\%), kandungan hemiselulosa yang rendah (2-4\%), serta sedikit residu lignin, ekstraktif dan mineral, hal yang berbeda dengan pulp untuk kertas (Sixta, 2006), serta memiliki reaktivitas yang baik terhadap bahan kimia tertentu, misalnya karbon disulfida (Miao et al., 2014).

Dissolving pulp merupakan produk penting yang dapat diperoleh dari kayu maupun nonkayu. Industri dissolving pulp umumnya menggunakan bahan baku kayu atau cotton linter (Dien et al., 2015). Namun demikian, tumbuhan nonkayu seperti residu pertanian, bagas, bambu dan lainnya merupakan sumber serat selulosa yang murah dan telah banyak menarik perhatian peneliti untuk digunakan sebagai bahan baku komposit, tekstil, pulp dan kertas (Wang and Chen, 2013; Reddy and Yang, 2005). Serat nonkayu memiliki sifat dan struktur morfologi yang hampir sama dengan kayu. Kelebihan nonkayu yaitu membutuhkan pengairan dan pemupukan sedang, siklus pertumbuhan tanaman yang pendek, dan kandungan lignin yang rendah sehingga mengurangi konsumsi energi dan bahan kimia selama pembuatan pulp. Selanjutnya, penggunaan nonkayu sebagai bahan baku bisa menghemat bahan baku kayu untuk keperluan lain dan mencegah deforestasi besar-besaran (Behin and Zeyghami, 2009; Rodríguez et al., 2008; Ververis et al., 2004).

Pulp dengan tingkat kemurnian tinggi dicapai melalui penghilangan hemiselulosa karena keberadaan hemiselulosa akan mengurangi kemampuan proses optimal selulosa, misalnya saat proses xanthasi dalam pembuatan viskosa rayon, menyebabkan filterabilitas yang buruk, dan pada produk akhir akan memiliki kekuatan yang rendah (Christov and Prior, 1993; Köpcke, 2010; Duan, Li, et al., 2015; J. Li et al. 2015). Proses pemurnian selulosa ini menyebabkan yield produksi dissolving pulp relatif lebih rendah dibandingkan dengan produksi pulp biasa, sehingga proses produksi dissolving pulp memerlukan biaya yang lebih tinggi (Sixta, 2006), dimana komponen utama biaya produksi tersebut mencakup modal, bahan kimia, tingkat produksi, serta penyimpanan (Kopcke, 2010). Saat ini dampak lingkungan yang terkait proses pembuatan dissolving pulp konvensional (kraft dan sulfit) juga ikut menjadi perhatian (Vila, Santos and Parajo, 2004).

Berdasarkan kondisi tersebut, diperlukan metode alternatif pembuatan dissolving pulp dengan proses yang lebih ramah lingkungan dan relatif hemat biaya. Upaya pemurnian pulp kertas yang murah menjadi dissolving pulp yang bernilai tinggi, menjadi salah satu metode alternatif yang telah cukup banyak dilaporkan (Puls, Janzon and Saake, 2006; Janzon et al., 2008; Köpcke, Ibarra and Ek, 2008; Ibarra, Kopcke and Ek, 2009; Froschauer et al., 2013; Kaur, Bhardwaj and Sharma, 2016). Tantangan utama konversi pulp kertas terletak pada penghilangan hemiselulosa didalam pulp kertas (Sixta, 2006). Produk akhir dari pulp ini adalah selulosa eter (karboksimetil selulosa), selofan, rayon, selulosa ester (asetat dan nitrat) dan derivat selulosa lainnya (Christov, Akhtar and Prior, 1998). Makalah ini akan memaparkan beberapa aspek penting terkait dissolving pulp yaitu bahan baku, proses pembuatan, dan karakteristik kunci. Bahan baku yang dibahas meliputi kayu sebagai pembanding dan beberapa jenis nonkayu seperti jute, bagas, kenaf, jerami padi dan bambu. Selain proses sulfit dan kraft dengan prahidrolisis, disinggung juga proses soda dan enzim, konversi dari pulp kertas. 
Tabel 1. Komposisi Kimia Beberapa Jenis Nonkayu dan Kayu

\begin{tabular}{|c|c|c|c|c|c|c|c|c|c|c|c|}
\hline Sifat & Bagas $^{1}$ & $\begin{array}{l}\text { Jerami } \\
\text { padi }^{2}\end{array}$ & $\begin{array}{l}\text { Batang } \\
\text { pisang }^{3}\end{array}$ & $\begin{array}{l}\text { Bambu } \\
\text { hijau }^{4}\end{array}$ & $\begin{array}{c}\text { Bambu } \\
\text { duri }^{5}\end{array}$ & $\begin{array}{l}\text { Bambu } \\
\operatorname{mayan}^{6}\end{array}$ & $\begin{array}{c}\text { Bambu } \\
\text { sembilang }\end{array}$ & Kenaf $^{7}$ & $\begin{array}{c}\text { Acacia } \\
\text { mangium }^{8}\end{array}$ & $\begin{array}{c}\text { Acacia } \\
\text { crassicarpa }^{9}\end{array}$ & $\begin{array}{l}\text { Eucalyptus } \\
\text { urograndis }^{10}\end{array}$ \\
\hline $\begin{array}{l}\text { Lignin Klason } \\
\text { (Klason lignin, \%) }\end{array}$ & 21,3 & 16,3 & 12.1 & 23,1 & $\begin{array}{c}23,20- \\
24,32\end{array}$ & 23,86 & 23,85 & $\begin{array}{c}10,16- \\
16,88\end{array}$ & 27,65 & $26,95-27,31$ & 26,30 \\
\hline $\begin{array}{l}\text { Selulosa } \\
\text { (Cellulose, \%) }\end{array}$ & - & 34,7 & - & 49,6 & $\begin{array}{c}49,44- \\
58,24\end{array}$ & 44,36 & 46,88 & $\begin{array}{c}39,46- \\
45,56\end{array}$ & 41,48 & $43,33-48,62$ & - \\
\hline $\begin{array}{l}\text { Pentosan } \\
(\text { Pentosan, \%) }\end{array}$ & - & 19,8 & - & 17,5 & $\begin{array}{l}13,91- \\
20,90\end{array}$ & 18,37 & 21,61 & $\begin{array}{l}16,92- \\
22,65\end{array}$ & 18,37 & $17,39-18,88$ & - \\
\hline $\begin{array}{l}\text { Glukan (Glucan, } \\
\% \text { ) }\end{array}$ & 41,6 & - & 39,4 & - & - & - & - & - & & - & 46,50 \\
\hline Xilan (Xylan, \%) & 18,9 & - & 19,5 & - & - & - & - & - & & - & 10,50 \\
\hline $\begin{array}{l}\text { Galaktan } \\
(\text { Galactan, \%) }\end{array}$ & 0,5 & - & - & - & - & - & - & - & & - & 0,90 \\
\hline $\begin{array}{l}\text { Mannan (Mannan, } \\
\% \text { ) }\end{array}$ & 0 & - & - & - & - & - & - & - & & - & 0,60 \\
\hline $\begin{array}{l}\text { Arabinan } \\
\text { (Arabinan, \%) }\end{array}$ & 1,2 & - & - & - & - & - & - & - & & - & 0,20 \\
\hline $\mathrm{Abu}(A s h, \%)$ & 4,0 & 11,2 & 18,3 & 1,8 & $2,59-4,52$ & 1,66 & 3,70 & $\begin{array}{c}3,50- \\
4,59\end{array}$ & 0,83 & $0,55-0,64$ & 0,02 \\
\hline Silika (Silica, \%) & 2,7 & - & - & - & $0,51-1,14$ & - & - & - & - & - & 0.04 \\
\hline $\begin{array}{l}\text { Ekstraktif } \\
\text { (Extractive, \%) }\end{array}$ & 8,5 & - & 3,7 & - & $3,10-4,80$ & 8,38 & 4,51 & $\begin{array}{c}2,00- \\
2,47\end{array}$ & - & $1,84-2,08$ & 2,90 \\
\hline
\end{tabular}

Keterangan : 1. Andrade and Colodette (2014); 2. Dien et al. (2015); 3. Das, Nakagawa-Izumi and Ohi (2016); 4. Luo et al. (2014); 5. Purwita and Sugesty (2017); 6. Sugesty, Kardiansyah and Hardiani (2015); 7. Sugesty and Setiawan (2013); 8. Sugesty and Setiawan (2012); 9. Sugesty, Kardiansyah and Pratiwi (2015); 10. Martino et al. (2017).

\section{Bahan Baku}

Pemilihan sumber kayu sebagai bahan baku untuk pulp didasarkan pada komposisi kimia yang dimilikinya. Kayu daun jarum dan kayu daun lebar mengandung selulosa sebesar 40-44\% (Desch and Dinwoodie, 1996). Beberapa tanaman pertanian memiliki kandungan selulosa yang sama atau bahkan melebihi kandungan selulosa dalam kayu. Pelepah kelapa sawit mengandung 49,8\% selulosa alfa, sedangkan kenaf, rumput ilalang, dan kapas mengadung selulosa lebih dari $40 \%$ (Ververis et al., 2004). Beberapa komposisi kimia dari tanaman nonkayu disajikan pada Tabel 1 .

Kandungan selulosa dari jerami paling rendah dibandingkan dengan batang pisang, bagas dan bambu, namun demikian keempat jenis bahan baku nonkayu tersebut telah dicoba potensinya sebagai bahan baku dissolving pulp. Kandungan selulosa dari bagas dan bambu di atas 40\% mendekati kadar selulosa dalam kayu. Kandungan hemiselulosa keempat jenis bahan baku nonkayu hampir sama yaitu sekitar 19\%. Kandungan abu batang pisang dan jerami padi cukup tinggi dibandingkan dengan bambu, bagas dan kayu Eucalyptus. Kadar ekstraktif bagas cukup tinggi dibandingkan dengan bambu dan batang pisang. Kadar abu dan ekstraktif yang tinggi akan berpengaruh pada proses produksi termasuk pada proses pemasakan, pemutihan dan pengolahan lindi hasil pemasakan (Cao et al., 2014; Ek, Gellerstedt and Henriksson, 2009). Kayu dengan dengan kadar ekstraktif yang rendah lebih disukai karena ekstraktif kayu akan mempengaruhi produk pulp dan meningkatkan kebutuhan bahan kimia pemasak untuk menghilangkan ekstraktif tersebut (Istikowati et al., 2016).

Keberadaan senyawa anorganik dalam dissolving pulp dapat mengganggu proses filterability dan menyebabkan penyumbatan pada unit pemintal serat rayon, sehingga kadar anorganik diusahakan agar serendah mungkin (Sixta, 2006). Ekstraktif menyebabkan masalah dalam proses pembuatan rayon viskosa seperti pengendapan viskosa, penyumbatan pada pemintal dan penguningan pada benang. Sehingga, diharapkan kandungannya sangat rendah di dalam dissolving pulp (Duan, Long, et al., 2015).

\section{Proses Pembuatan Dissolving Pulp}

Xilan merupakan komponen utama hemiselulosa pada hardwood, sekitar 30\% dinding sel tumbuhan terdiri dari xilan (Awano, Takabe and Fujita, 2001). Sedangkan pada softwood, 
komponen utama hemiselulosa didominasi oleh galactoglucomannan (15-20\%) dan xilan terkandung sekitar 7-10\%. Baik softwood dan hardwood mengandung sejumlah kecil komponen hemiselulosa lainnya seperti galaktan dan arabinans (Schaechter, 2009). Penghilangan komponen hemiselulosa ini dapat dilakukan melalui beberapa cara. Secara komersial, sekitar 85-88\% produksi dissolving pulp saat ini diperoleh melalui proses prahidrolisis kraft (PHK) ataupun proses asam sulfit yang diikuti dengan tahap pemutihan dan pemurnian (Sixta, 2006; Gehmayr, Potthast and Sixta, 2012; Jarriault et al., 2014; Li et al., 2015). Pada awalnya proses asam sulfit merupakan metode yang paling banyak digunakan, sekitar $65 \%$ produksi dunia menggunakan proses ini dengan $25 \%$ sisanya menggunakan proses PHK (Sixta, 2006). Pada akhir tahun 2014 proses PHK menyumbang $56 \%$ produksi dissolving pulp dunia, sementara proses asam sulfit menyumbang $42 \%$ (Chen et al., 2016). Metode terbaru pembuatan dissolving pulp adalah konversi dari pulp kertas menjadi dissolving pulp menggunakan bahan kimia atau enzim, ataupun kombinasi dari penggunaan bahan kimia dengan enzim.

\section{A. Metode Konvensional}

\section{Proses Bisulfit}

Dissolving pulp dibuat melalui proses pulping menggunakan sulfur dioksida (Woodings, 2001). Larutan pemasak dibuat dari pembakaran sulfur untuk menghasilkan gas $\mathrm{SO}_{2}$ yang diserap dalam larutan basa kationik (umumnya basa kation yang digunakan adalah kalsium, magnesium, sodium dan amonia) (Saka and Matsumura, 2004). Serpihan kayu kemudian dimasak dalam larutan pemasak yang mengandung asam sulfur $\left(\mathrm{H}_{2} \mathrm{SO}_{3}\right)$ dan alkalin. Sulfonasi dimulai saat suhu di atas $110{ }^{\circ} \mathrm{C}$. Proses ini dijalankan pada temperatur $160-180 \quad{ }^{\circ} \mathrm{C}$ dengan lama waktu pemasakan 0,25-3 jam dengan yield akhir 55-75\% (Biermann, 1996). Referensi lain menyatakan kondisi pemasakan proses ini adalah pada suhu antara 130 dan $150^{\circ} \mathrm{C}$ dengan tekanan berkisar 75 dan 125 psi selama 4 hingga 8 jam (Saka and Matsumura, 2004). Namun umumnya suhu yang digunakan $140-160{ }^{\circ} \mathrm{C}$ tergantung pada keasaman larutan pemasak, saat $\mathrm{pH}$ asam memerlukan suhu yang lebih rendah, sedangkan $\mathrm{pH}$ tinggi dapat menggunakan suhu yang lebih tinggi (Woodings, 2001). Kelemahan utama dari proses pembuatan pulp asam sulfit adalah distribusi berat molekul (MWD) yang agak luas dari pulp yang dihasilkan, biaya investasi cukup tinggi, dan viskositas rendah (Sixta et al., 2004).

\section{Proses Sulfit-Soda}

Proses ini biasanya menggunakan dua tahap sulfit-soda (Sivola) atau tiga tahap bisulfit-sulfitsoda (Rauma). Tujuan tahap sulfit adalah untuk meningkatkan proses delignifikasi, sedangkan tahap soda adalah untuk mengontrol tingkat kandungan selulosa alfa dan viskositas. Proses ini dilakukan pada $\mathrm{pH}$ 5-10, dengan suhu 145-180 ${ }^{\circ} \mathrm{C}$ dan waktu 1-4 jam. Kandungan selulosa alfa yang diperoleh dari proses bisulfitsulfit-soda mencapai hingga 96\% (Rauma) dan 95\% untuk proses sulfit soda (Sivola) dengan kondisi suhu pemasakan $170{ }^{\circ} \mathrm{C}$ pada $\mathrm{pH} 8$ (Sixta, 2006). Sekarang, proses ini sudah tidak digunakan lagi (Woodings, 2001).

\section{Proses Prahidrolisis Kraft (PHK)}

Tahapan hidrolisis dalam proses pembuatan dissolving pulp dapat berlangsung melalui fase cair ataupun gas. Ekstraksi dengan fase cair dilakukan mengunakan air panas pada suhu tinggi (140-170 ${ }^{\circ} \mathrm{C}$ ) (Fatehi and Ni, 2011), sedangkan hidrolisis uap menggunakan penguapan langsung pada suhu antara 160 dan $170{ }^{\circ} \mathrm{C}$ selama 1-3 jam. Prahidrolisis dapat dilakukan juga dengan menggunakan asam sulfat $1 \mathrm{~N}$ dengan perbandingan padatan dan cair adalah 1: $5(\mathrm{w} / \mathrm{v})$ pada suhu $160{ }^{\circ} \mathrm{C}$ selama 145 menit (Purwita and Sugesty, 2018). Referensi lain menyatakan bahwa hidrolisis bisa dilakukan menggunakan air pada suhu $160-180^{\circ} \mathrm{C}$, atau asam encer $(0,3-$ $0,5 \% \mathrm{H}_{2} \mathrm{SO}_{4}$ pada suhu $120-140{ }^{\circ} \mathrm{C}$ ), maupun asam pekat $\left(20-30 \% \mathrm{HCl}\right.$ pada suhu $\left.40{ }^{\circ} \mathrm{C}\right)$ (Sixta, 2006). Pulp yang telah terhidrolisis kemudian dimasak dengan natrium hidroksida dan natrium sulfida $\left(\mathrm{NaOH}+\mathrm{Na}_{2} \mathrm{~S}\right)$ (Saka and Matsumura, 2004).

Bahan utama yang aktif dalam proses PHK adalah anion hidroksida dan hidrosulfida, ion hidrosulfida berperan mempercepat delignifikasi dalam proses pulping dan mengubah soda pemasak non-selektif menjadi proses delignifikasi yang selektif (Sixta, 2006). Penghilangan hemiselulosa umumnya terjadi pasca ekstraksi oleh alkali (Gehmayr, Schild and Sixta, 2011). Pada tahap prahidrolisis, beberapa senyawa organik seperti 
Tabel 2. Proses Pembuatan Dissolving Pulp Beberapa Jenis Nonkayu dan Kayu

\begin{tabular}{|c|c|c|c|c|c|c|c|c|c|c|c|c|c|}
\hline $\begin{array}{l}\text { Parameter } \\
\text { proses }\end{array}$ & Bagas $^{1}$ & $\begin{array}{l}\text { Jerami } \\
\text { padi }^{2}\end{array}$ & $\begin{array}{l}\text { Batang } \\
\text { pisang }^{3}\end{array}$ & $\begin{array}{c}\text { Bambu } \\
\text { hijau }^{4}\end{array}$ & $\begin{array}{c}\text { Bambu } \\
\text { duri }^{5}\end{array}$ & $\begin{array}{l}\text { Bambu } \\
\text { mayan }^{6}\end{array}$ & $\begin{array}{c}\text { Bambu } \\
\text { sembil- } \\
\text { ang }^{6}\end{array}$ & Kenaf $^{7}$ & $\begin{array}{l}\text { Jute }^{8} \\
\text { (Jute) }\end{array}$ & $\begin{array}{c}\text { Acacia } \\
\text { mangi- } \\
\text { um }^{9}\end{array}$ & $\begin{array}{c}\text { Acacia } \\
\text { crassicar- } \\
\text { pa }^{I 0}\end{array}$ & \multicolumn{2}{|c|}{$\begin{array}{l}\text { Eucalyptus } \\
\text { urograndis }^{11}\end{array}$} \\
\hline $\begin{array}{l}\text { Prahidrolisis } \\
\text { (Prehydro- } \\
\text { lysis) }\end{array}$ & Air & $\begin{array}{l}\text { Asam } \\
\text { encer }\end{array}$ & Air & Air & $\begin{array}{l}\text { Asam } \\
\text { encer }\end{array}$ & $\begin{array}{l}\text { Asam } \\
\text { encer }\end{array}$ & $\begin{array}{l}\text { Asam } \\
\text { encer }\end{array}$ & $\begin{array}{l}\text { Air, } \\
\text { Asam } \\
\text { encer }\end{array}$ & Air & $\begin{array}{l}\text { Air, } \\
\text { Asam } \\
\text { encer }\end{array}$ & $\begin{array}{l}\text { Asam } \\
\text { encer }\end{array}$ & \multicolumn{2}{|c|}{ Air } \\
\hline $\begin{array}{l}\text { Suhu (Tem- } \\
\text { perature, } \\
\left.{ }^{\circ} \mathrm{C}\right)\end{array}$ & 180 & $70-120$ & 150 & $\begin{array}{l}150- \\
180\end{array}$ & 160 & - & - & 135 & $150-170$ & 165 & - & \multicolumn{2}{|c|}{-} \\
\hline $\begin{array}{l}\text { Waktu tuju } \\
\text { (Time to, } \\
\text { minutes) }\end{array}$ & 60 & - & - & - & 55 & - & - & - & 35 & - & - & \multicolumn{2}{|c|}{-} \\
\hline $\begin{array}{l}\text { Waktu pada } \\
\text { (Time at, } \\
\text { minutes) }\end{array}$ & 15 & $20-60$ & 90 & $30-120$ & 90 & - & - & 120 & $60-120$ & 120 & - & \multicolumn{2}{|c|}{46,50} \\
\hline $\begin{array}{l}\text { Rasio } \\
\text { cairan:kayu } \\
\text { (Liq- } \\
\text { uid:wood } \\
\text { Ratio) }\end{array}$ & $8: 1$ & 10:1 & $7: 1$ & $3: 1$ & $5: 1$ & - & - & $5: 1$ & $5: 1$ & $4: 1$ & - & \multicolumn{2}{|c|}{10,50} \\
\hline $\begin{array}{l}\text { Proses } \\
\text { pemasakan } \\
\text { (Pulping } \\
\text { process) }\end{array}$ & Soda & Kraft & $\begin{array}{l}\text { Kraft, } \\
\text { Soda, } \\
\text { AS }\end{array}$ & Kraft & Kraft & Kraft & Kraft & Kraft & Kraft & Kraft & Kraft & $\begin{array}{l}\text { Or- } \\
\text { gano- } \\
\text { solv }\end{array}$ & Kraft \\
\hline $\begin{array}{l}\text { Suhu (Tem- } \\
\text { perature, } \\
\left.{ }^{\circ} \mathrm{C}\right)\end{array}$ & 180 & $80-120$ & 150 & 170 & 160 & 165 & 165 & 160 & 170 & 165 & 165 & 170 & 162 \\
\hline $\begin{array}{l}\text { Waktu tuju } \\
\text { (Time to, } \\
\text { minutes) }\end{array}$ & 60 & - & - & 60 & 90 & - & - & - & - & 90 & 120 & 50 & 60 \\
\hline $\begin{array}{l}\text { Waktu pada } \\
\text { (Time at, } \\
\text { minutes) }\end{array}$ & 20 & $80-120$ & $30-90$ & - & 120 & - & - & 180 & 120 & 120 & 90 & 60 & 15 \\
\hline $\begin{array}{l}\text { Rasio } \\
\text { lindi:kayu } \\
\text { (liquor:wood } \\
\text { ratio) }\end{array}$ & $8: 1$ & 10:1 & $7: 1$ & $3: 1$ & - & $5: 1$ & $5: 1$ & $5: 1$ & $5: 1$ & $4: 1$ & $4: 1$ & $7: 1$ & $4: 1$ \\
\hline $\begin{array}{l}\text { Dosis alkali } \\
\text { (Alkali } \\
\text { dosage, \%) }\end{array}$ & $\begin{array}{c}12,5 \\
15\end{array}$ & $10-30$ & $20 ; 25^{*}$ & $21-23$ & 16 & $20-22$ & $20-22$ & 16 & $14-18$ & 18 & $20-22$ & - & 25 \\
\hline $\begin{array}{l}\text { Sulfiditas } \\
\text { (Sulfidity, \%) }\end{array}$ & - & 25 & $25 ; 30$ & 26 & 30 & $30-32$ & $30-32$ & 28 & 27 & 32 & 30 & - & 25 \\
\hline $\begin{array}{l}\text { Rasio eta- } \\
\text { nol:air } \\
\text { (Ethanol:wa- } \\
\text { ter ratio) }\end{array}$ & - & - & - & - & - & - & - & - & - & - & - & $65: 35$ & - \\
\hline $\begin{array}{l}\text { Asam sulfat } \\
\text { (Sulphuric } \\
\text { acid,\%) }\end{array}$ & - & - & - & - & - & - & - & - & - & - & - & 0,5 & - \\
\hline $\begin{array}{l}\text { Proses } \\
\text { pemutihan } \\
\text { (Bleaching } \\
\text { process) }\end{array}$ & ECF & ECF & ECF & ECF & ECF & ECF & ECF & ECF & ECF & ECF & ECF & EC & \\
\hline $\begin{array}{l}\text { Rangkaian } \\
\text { (Sequences) }\end{array}$ & $\begin{array}{l}\mathrm{O}_{-} \mathrm{D}_{0}^{-} \\
(\mathrm{Ep})- \\
\mathrm{D}_{1}-\mathrm{P}\end{array}$ & $\begin{array}{c}\mathrm{D}_{0^{-}} \\
\text {(Eop)- } \mathrm{D}_{1}\end{array}$ & $\begin{array}{c}\mathrm{D}_{0}-\mathrm{D}_{1^{-}} \\
\mathrm{D}_{2}-\mathrm{D}_{3^{-}} \\
\mathrm{Ep}\end{array}$ & $\begin{array}{c}\mathrm{D}_{0}^{-} \\
\mathrm{E}-\mathrm{D}_{1}\end{array}$ & $\begin{array}{c}\mathrm{D}_{0}-\mathrm{E}- \\
\mathrm{D}_{1}-\mathrm{D}_{2} \\
\mathrm{D}_{0}-\mathrm{Ep}- \\
\mathrm{D}_{1}-\mathrm{D}_{2}\end{array}$ & $\begin{array}{c}{\mathrm{O}-\mathrm{D}_{0}-}^{-} \\
\text {Eo- } \\
\mathrm{D}_{1}-\mathrm{D}_{2} \\
\text { X-O-D } \\
\text { Eo-D }{ }_{1}-\end{array}$ & $\begin{array}{c}{\mathrm{O}-\mathrm{D}_{0}-}^{-} \\
\text {Eo- } \\
\mathrm{D}_{1}-\mathrm{D}_{2} \\
\text { X-O-D } \\
\text { Eo- } \mathrm{D}_{1}-\end{array}$ & $\begin{array}{l}\mathrm{X}-\mathrm{O}-\mathrm{D}_{0}- \\
\text { Eo-D }-\mathrm{D}_{1}-\mathrm{D}_{2}\end{array}$ & $\begin{array}{c}\mathrm{D}_{0}-\mathrm{Ep}- \\
\mathrm{D}_{1}-\mathrm{Ep}-\mathrm{D}_{2}\end{array}$ & $\begin{array}{c}\text { X-O-D - } \\
\text { Eo- } \\
D_{1}-D_{2}\end{array}$ & $\begin{array}{l}\mathrm{O}-\mathrm{D}_{0}-\mathrm{E}- \\
\mathrm{D}_{1}-\mathrm{E}-\mathrm{D}_{2} \\
\mathrm{X}-\mathrm{D}_{0}-\mathrm{E}- \\
\mathrm{D}_{1}-\mathrm{E}-\mathrm{D}_{2}\end{array}$ & $\begin{array}{r}\mathrm{O}-\mathrm{D}_{0}-\mathrm{-} \\
\mathrm{D}_{1}-\end{array}$ & $\begin{array}{l}\text { EH)- } \\
\text { P }\end{array}$ \\
\hline
\end{tabular}

Keterangan: AS (Alkali sulfit), *(NaOH:Na2SO3=70:30; Anthraquinon 0,1\%), ECF (Elemental-Chlorune Free), O=Oksigen, D=Klorin dioksida, Ep=Ekstraksi alkali dengan Hidrogen Peroksida, Eop= Ekstraksi alkali dengan Oksigen dan Hidrogen Peroksida, E= Ekstraksi alkali, EH= Ekstraksi alkali dengan Hipoklorit. 1. Andrade and Colodette (2014); 2. Dien et al. (2015); 3. Das, Nakagawa-Izumi and Ohi (2016); 4. Luo et al. (2014); 5.(Purwita and Sugesty, 2017); 6. Sugesty, Kardiansyah and Hardiani (2015); 7. Sugesty and Setiawan (2013); 8. Matin et al. (2015); 9. Sugesty and Setiawan (2012); 10. Sugesty, Kardiansyah and Pratiwi (2015); 11. Martino et al. (2017). 
lignin, furfural dan asam asetat, terlarut atau membentuk tambahan pada hemiselulosa yang terlarut (Liu, Fatehi and Ni, 2011). Saat hidrolisis, gugus asetil dan formil dari kayu membentuk asam asetat dan asam format, menyebabkan $\mathrm{pH}$ menjadi 3,5 didalam kayu. Komponen kayu mulai terdepolimerisasi seiring dimulainya hidrolisis asam sehingga mengurangi massa kayu sebesar $5-20 \%$, dimana pengurangannya tergantung pada lama waktu proses hidrolisis serta suhu. Jika proses hidrolisis berlangsung dalam waktu yang lebih lama akan mempengaruhi selulosa, sehingga menghasilkan yield selulosa yang rendah dan lebih banyak lignin terkondensasi (Woodings, 2001). Jahan et al. (2008) melakukan modifikasi proses PHK dengan menambahkan soda-ethylene-diamine (EDA) dalam larutan pemasak sehingga diperoleh dissolving pulp dari Trema orientalis dengan tingkat kemurnian tinggi. EDA mampu secara selektif memisahkan lignin dan hemiselulosa dengan mempertahankan selulosa alfa.

Karakteristik pulp dari proses PHK memiliki kandungan selulosa alfa yang lebih tinggi, nilai $\mathrm{S}_{10} / \mathrm{S}_{18}$ yang lebih rendah, dan distribusi berat molekul (MWD) yang lebih sempit dibandingkan dengan pulp dari proses asam sulfit (Duan, Li, et al., 2015). Metode PHK dapat diaplikasikan pada lebih banyak jenis kayu dibandingkan proses sulfit, sehingga metode PHK dapat digunakan secara luas (Saka and Matsumura, 2004). Namun proses prahidrolisis kraft juga memiliki kelemahan yang penting, yaitu adanya pembentukan intermediet yang sangat reaktif dalam prahidrolisat yang dihasilkan, dan ketika terjadi kondensasi akan membentuk endapan yang lengket saat drainase (Gehmayr, Schild and Sixta, 2011). Metode PHK juga memiliki potensi kerugian karena losses selulosa yang cukup besar (15-30\%) disebabkan reaksi pengelupasan yang terjadi (Froschauer et al., 2013).

Proses pemasakan yang digunakan dalam pembuatan dissolving pulp nonkayu pada Tabel 2 umumnya menggunakan proses kraft, namun demikian ada juga yang menggunakan proses soda. Proses pemutihan pada seluruh pembuatan dissolving pulp baik nonkayu maupun kayu menggunakan proses ECF (Elemental-Chlorine Free). Proses pemutihan ECF merupakan proses pemutihan bebas senyawa klorin elementer $\left(\mathrm{Cl}_{2}\right)$, tetapi masih menggunakan senyawa klorin dalam bentuk klorin dioksida $\left(\mathrm{ClO}_{2}\right)$. Tujuan utama dari proses pemutihan adalah untuk mengoksidasi lignin secara selektif dan meminimalisasi oksidasi selulosa. Pemutihan dapat mereduksi bilangan kappa, tanpa menurunkan derajat polimerisasi pulp secara drastis (Behin and Zeyghami, 2009).

\section{B. Metode Konversi dari Pulp Kertas}

Sebagai alternatif telah dipelajari potensi pulp kertas yang relatif lebih murah untuk dikonversi menjadi dissolving pulp melalui reduksi hemiselulosa, relatif hemat biaya, dan ramah bagi industri (Ibarra et al., 2010; Li et al., 2012). Pulp kertas memiliki reaktivitas yang rendah dan kandungan hemiselulosa yang tinggi sehingga tidak dapat digunakan langsung sebagai bahan baku produk derivat selulosa. Hal utama yang perlu dilakukan adalah pengurangan hemiselulosa ke tingkat yang dapat diterima sebelum meningkatkan reaktivitasnya (Kaur, Bhardwaj and Sharma, 2016). Hal lain yang perlu diperhatikan adalah meningkatkan aksesibilitas selulosa dan mengendalikan derajat polimerisasi (DP) (Gehmayr and Sixta, 2011; Li et al., 2012). Ada beberapa metode untuk mengubah pulp kertas menjadi dissolving pulp seperti : proses ekstraksi kaustik, ekstraksi organosolv, ekstraksi cairan ionik, kombinasi penggunaan enzim (xilanase, endoglukanase) dan juga pra-perlakuan secara mekanis

\section{Metode Konversi Konvensional}

\section{a. Ekstraksi Kaustik}

Pulp kertas dapat dikonversi menjadi dissolving pulp melalui ekstraksi kaustik, dengan cara menghilangkan karbohidrat rantai pendek yang bertahan selama proses pembuatan pulp. Pemurnian dengan metode alkali ini dapat dilakukan dengan dua cara yaitu proses dingin/Cold Caustic Extraction (CCE) dijalankan pada suhu $20-40{ }^{\circ} \mathrm{C}$ dengan konsentrasi natrium hidroksida tinggi (1,2-3,0 mol/L), atau ekstraksi kaustik panas/ Hot Caustic Extraction (HCE) yang dijalankan pada suhu $70{ }^{\circ} \mathrm{C}$ dan $130{ }^{\circ} \mathrm{C}$ dengan konsentrasi natrium hidroksida rendah $(0,1-0,4 \mathrm{~mol} / \mathrm{L})$ (Sixta, 2006). Hasil yield yang diperoleh dari proses HCE kurang menguntungkan karena proses ini memerlukan energi yang sangat besar, serta HCE juga kurang selektif (Schild and Sixta, 2011). Hal ini diperkuat dengan penelitian (Jarriault et al., 2014) bahwa yield dari dissolving pulp yang diperoleh dari proses $\mathrm{HCE}+$ asam panas adalah 
Tabel 3. Referensi Proses Pembuatan Dissolving Pulp Konversi dari Pulp Kertas

\begin{tabular}{|c|c|c|c|c|c|c|c|c|}
\hline Bahan Baku & Metode & $\begin{array}{l}\text { Bahan } \\
\text { Kimia }\end{array}$ & $\begin{array}{l}\alpha \text {-selulosa } \\
(\%)\end{array}$ & $\begin{array}{c}\text { Hemiselu- } \\
\text { losa (\%) }\end{array}$ & $\begin{array}{l}\text { Yield } \\
(\%)\end{array}$ & $\begin{array}{c}\text { Reakti- } \\
\text { vitas }\end{array}$ & Viskositas & Referensi \\
\hline \multirow[t]{3}{*}{$\begin{array}{l}\text { E. urograndis pulp } \\
\text { kraft }\end{array}$} & IONCELL & $\begin{array}{l}\text { 1-ethyl-3- } \\
\text { methylimidazolium } \\
\text { dimethylphosphate }\end{array}$ & - & 2,2 & 97,7 & - & - & \multirow[t]{3}{*}{ Roselli et al. (2014) } \\
\hline & Enzim+ IONCELL & $\begin{array}{l}\text { Endoxylanase (Pulpzyme) } \\
\text { + EMIM DMP }\end{array}$ & - & 1,7 & 92,3 & - & - & \\
\hline & CCE & $\mathrm{NaOH}$ & - & 3,9 & 79,5 & - & - & \\
\hline \multirow[t]{2}{*}{ Birch pulp kraft } & IONCELL + CCE & $\begin{array}{l}\text { 1-ethyl-3- } \\
\text { methylimidazolium } \\
\text { acetate (EMIM OAc) }\end{array}$ & 96,9 & 3,1 & - & - & - & \multirow[t]{2}{*}{$\begin{array}{l}\text { Froschauer et al. } \\
\text { (2013) }\end{array}$} \\
\hline & IONCELL & NMMO & 88,6 & 11,4 & - & - & - & \\
\hline $\begin{array}{l}\text { Softwood pulp } \\
\text { kraft }\end{array}$ & IONCELL & $\begin{array}{l}\text { 1-ethyl-3- } \\
\text { methylimidazolium } \\
\text { acetate }\end{array}$ & 96,7 & 1 & 83 & - & $880 \mathrm{~mL} \mathrm{~g}^{-1}$ & Laine et al. (2016) \\
\hline $\begin{array}{l}\text { Eucalyptus } \\
\text { globulus pulp kraft }\end{array}$ & $\begin{array}{l}\text { CCE+ oksidasi } \\
\text { TEMPO }\end{array}$ & $\begin{array}{l}\mathrm{NaOH}, \\
\text { 2,2,6,6-tetramethylpiper- } \\
\text { idin }\end{array}$ & 94,8 & 4,7 & - & - & $450 \mathrm{~mL} \mathrm{~g}^{-1}$ & $\begin{array}{l}\text { Gehmayr, Potthast and } \\
\text { Sixta (2012) }\end{array}$ \\
\hline \multirow{2}{*}{$\begin{array}{l}\text { Softwood pulp } \\
\text { kraft }\end{array}$} & CCE & $\mathrm{NaOH}$ & 93,7 & 1,6 & 90 & - & - & \multirow[t]{2}{*}{ Jarriault et al. (2014) } \\
\hline & $\begin{array}{l}\text { Asam panas }+ \\
\text { HCE (Hot Caustic } \\
\text { Extraction) }\end{array}$ & $\mathrm{NaOH}$ & - & 2,9 & 74 & - & - & \\
\hline \multirow{2}{*}{$\begin{array}{l}\text { Softwood pulp } \\
\text { sulfit }\end{array}$} & CCE & $\mathrm{NaOH}$ & - & 7,8 & 96,5 & $39,5 \%$ & - & \multirow[t]{2}{*}{ Li et al. (2015) } \\
\hline & Mekanis+ CCE & $\mathrm{NaOH}$ & - & 4,8 & 94,3 & $43,8 \%$ & - & \\
\hline $\begin{array}{l}\text { E. globulus pulp } \\
\text { kraft }\end{array}$ & Enzim $+\mathrm{CCE}$ & $\begin{array}{l}\text { Xylanase } \\
\text { Endoglucanase } \\
\text { (Novozyme 476) } \\
\mathrm{NaOH}\end{array}$ & 95,9 & 4,7 & - & $26,8 \%$ & $420 \mathrm{~mL} \mathrm{~g}^{-1}$ & $\begin{array}{l}\text { Gehmayr and Sixta } \\
(2011)\end{array}$ \\
\hline \multirow[t]{3}{*}{ Eucalyptus } & \multirow[t]{3}{*}{ Organosolv } & Milox & - & 1,4 & - & FV 232 & $245 \mathrm{~mL} \mathrm{~g}^{-1}$ & \multirow[t]{3}{*}{ Sixta et al. (2004) } \\
\hline & & Acetosolv & - & 3,7 & - & FV 52 & $245 \mathrm{~mL} \mathrm{~g}^{-1}$ & \\
\hline & & Formacell & - & 2,5 & - & FV 385 & $232 \mathrm{~mL} \mathrm{~g}^{-1}$ & \\
\hline Beech pulp & Organosolv & Acetosolv & - & 4,5 & - & - & $604 \mathrm{~cm}^{3} \mathrm{~g}^{-1}$ & $\begin{array}{l}\text { Vila, Santos and } \\
\text { Parajo (2004) }\end{array}$ \\
\hline Birch pulp kraft & Kompleks logam & Nitren & 96 & 3,3 & - & - & $890 \mathrm{~mL} \mathrm{~g}^{-1}$ & $\begin{array}{l}\text { Janzon, Puls and } \\
\text { Saake (2006) }\end{array}$ \\
\hline \multirow{3}{*}{$\begin{array}{l}\text { Eucalyptus pulp } \\
\text { kraft }\end{array}$} & \multirow{6}{*}{$\begin{array}{l}\text { Kompleks logam } \\
\text { + alkali }\end{array}$} & Nitren & 97 & 2,5 & - & - & - & \multirow{6}{*}{$\begin{array}{l}\text { Puls, Janzon and } \\
\text { Saake (2006) }\end{array}$} \\
\hline & & $\mathrm{NaOH}$ & 97,1 & 2,5 & - & - & - & \\
\hline & & $\mathrm{KOH}$ & 96,3 & 2,9 & - & - & - & \\
\hline \multirow[t]{3}{*}{ Birch pulp kraft } & & Nitren & 96 & 3,5 & - & - & - & \\
\hline & & $\mathrm{NaOH}$ & 95 & 4,7 & - & - & - & \\
\hline & & $\mathrm{KOH}$ & 95,4 & 4 & - & - & - & \\
\hline Maple pulp kraft & $\begin{array}{l}\text { Mekanis }+\mathrm{CCE}+ \\
\text { enzim }\end{array}$ & $\begin{array}{l}\mathrm{NaOH}, \\
\text { EG-rich cellulase }\end{array}$ & - & 4,46 & - & $81 \%$ & $402 \mathrm{~mL} \mathrm{~g}^{-1}$ & $\begin{array}{l}\text { Duan, Verma, et al. } \\
\text { (2015) }\end{array}$ \\
\hline Bambu pulp PHK & Mekanis + enzim & Xylanase & 93,4 & 2,38 & - & $32,42 \%$ & $6,1 \mathrm{mPa} . \mathrm{S}$ & Zhao et al. (2017) \\
\hline $\begin{array}{l}\text { Mixed hardwood } \\
\text { softwood pulp }\end{array}$ & Enzim & $\begin{array}{l}\text { Endoglukanase } \\
\text { (Novozyme N476) }\end{array}$ & - & - & 98,7 & $90,9 \%$ & $343 \mathrm{~mL} \mathrm{~g}^{-1}$ & $\begin{array}{l}\text { Henriksson, } \\
\text { Christiernin and } \\
\text { Agnemo (2005) }\end{array}$ \\
\hline $\begin{array}{l}\text { E. globulus pulp } \\
\text { kraft }\end{array}$ & \multirow[t]{2}{*}{ Enzim+ alkali } & \multirow{2}{*}{$\begin{array}{l}\mathrm{NaOH}, \\
\text { Xylanase (Pulpzyme HC), } \\
\text { Endoglucanase (N476) }\end{array}$} & 97,6 & 2,4 & - & $70,3 \%$ & $\begin{array}{c}220 \mathrm{dm}^{3} \\
\mathrm{~kg}^{-1}\end{array}$ & \multirow[t]{2}{*}{$\begin{array}{l}\text { Kopcke, Ibarra and Ek } \\
(2008)\end{array}$} \\
\hline Birch pulp kraft & & & 95,2 & 3,8 & - & $66 \%$ & $\begin{array}{c}190 \mathrm{dm}^{3} \\
\mathrm{~kg}^{-1}\end{array}$ & \\
\hline $\begin{array}{l}\text { Agave sisalana } \\
\text { pulp soda/AQ }\end{array}$ & Enzim+ alkali & $\begin{array}{l}\mathrm{NaOH}, \\
\text { Novozyme } 476, \\
\text { Pulpzyme HC }\end{array}$ & 95,5 & 3,9 & - & $66,2 \%$ & $290 \mathrm{~mL} \mathrm{~g}^{-1}$ & Ibarra et al. (2010) \\
\hline $\begin{array}{l}\text { E. globulus pulp } \\
\text { kraft }\end{array}$ & Enzim+ alkali & $\begin{array}{l}\text { Xylanase (Pulpzyme HC), } \\
\text { Endoglucanase (N476), } \\
\mathrm{NaOH}\end{array}$ & 95,9 & 4,7 & 99,3 & $\begin{array}{c}\text { Filter } \\
\text { Value } \\
171\end{array}$ & $420 \mathrm{~mL} \mathrm{~g}^{-1}$ & $\begin{array}{l}\text { Gehmayr, Schild and } \\
\text { Sixta (2011) }\end{array}$ \\
\hline $\begin{array}{l}\text { Softwood pulp } \\
\text { kraft }\end{array}$ & $\begin{array}{l}\text { Enzim + alkali } \\
\text { peroksida }\end{array}$ & $\begin{array}{l}\mathrm{NaOH}, \\
\mathrm{H} 2 \mathrm{O} 2, \\
\text { EG-rich cellulase }\end{array}$ & 92,1 & - & 79,8 & $68,7 \%$ & $\begin{array}{l}506,9 \mathrm{~mL} \\
\mathrm{~g}^{-1}\end{array}$ & Wang et al. (2014) \\
\hline $\begin{array}{l}\text { Mixed hardwood } \\
\text { pulp kraft }\end{array}$ & Enzim + alkali & $\begin{array}{l}\text { Xylanase, } \\
\mathrm{NaOH}\end{array}$ & 97,1 & $<8$ & 89,9 & $33 \%$ & $9,1 \mathrm{cP}$ & $\begin{array}{l}\text { Kaur, Bhardwaj and } \\
\text { Sharma (2016) }\end{array}$ \\
\hline
\end{tabular}


sebesar $74 \%$, lebih rendah dibandingkan dengan yield dari proses CCE sebesar 90\%. Metode CCE yang umum digunakan adalah ekstraksi kaustik menggunakan $\mathrm{NaOH}$ pada konsentrasi 8-10\% (Chen et al., 2016). Kekurangan metode CCE adalah efisiensi penghilangan hemiselulosa masih cukup terbatas, terutama untuk pulp yang berasal dari kayu daun jarum (softwood), karena glukomanan hanya diekstraksi sebagian (Sixta et al., 2013). Hal lain yang perlu dipertimbangkan dari metode CCE adalah hilangnya yield selulosa $1,2-1,5 \%$ untuk setiap peningkatan $1 \%$ kandungan selulosa alfa, serta konsumsi natrium hidroksida yang tinggi (Roselli et al., 2014). Gehmayr, Potthast and Sixta (2012) menyatakan kelemahan lain metode CCE adalah dissolving pulp yang dihasilkan masih memiliki reaktivitas yang rendah. Tabel 3 menyajikan referensi proses pembuatan dissolving pulp dari pulp kertas.

\section{b. Organosolv}

Metode organosolv menggunakan pelarut organik untuk menghilangkan lignin (Sixta, 2006). Pembuatan pulp secara organosolv juga menarik karena dapat diterapkan pada pabrik skala kecil dan tanpa menggunakan bahan kimia yang mengandung sulfur sehingga mendukung penggunaan pulp yang telah diputihkan dengan metode Totally Chlorine Free (TCF) (Alvarez and Tjeerdsma, 1995; Vila, Santos and Parajo, 2004). Pelarut yang diketahui digunakan untuk membuat pulp diantaranya methanol, ethanol, asam format, asam asetat, phenol dan cresol, etil asetat, amina dan amina oksida, keton, dioxan dan senyawa organik lainnya (Muurinen, 2000; Zhao, Cheng and Liu, 2009). Proses organosolv tidak mandiri energi. Kelemahan lain adalah harga bahan kimia pelarut organik yang mahal sehingga diperlukan proses recovery bahan kimia yang sangat baik, namun hal ini juga akan meningkatkan kebutuhan energi dan biaya produksi. Metode organosolv juga memiliki potensi kebakaran dan ledakan yang cukup tinggi (Muurinen, 2000; Bajpai, 2018). Hambatan-hambatan tersebut membatasi metode organosolv untuk digunakan secara luas (Bajpai, 2018). Tabel 3 menyajikan referensi proses pembuatan dissolving pulp dari pulp kertas.

\section{c. Kompleks Logam}

Metode alternatif lain yang telah dipatenkan untuk membuat dissolving pulp dari pulp kertas adalah penggunaan pelarut yang mengandung kompleks logam. Pada prinsipnya, metode ini menggunakan pelarut selektif hemiselulosa yang mengandung kompleks logam seperti Nitren dan Cuen (Puls, Janzon and Saake, 2006; Janzon, Puls and Saake, 2006; Janzon et al., 2008; Janzon, Saake and Puls, 2008). Nitren adalah sebuah kompleks nikel (tris (2-aminoetil) amina) yang mampu melarutkan xilan melalui ekstraksi pulp selama 1 jam pada suhu $30{ }^{\circ} \mathrm{C}$ diikuti dengan filtrasi hemiselulosa terlarut. Penggunaan nitren ini dilaporkan mampu mengurangi kandungan xilan dalam pulp kraft dengan selektivitas yang lebih baik daripada cuen (pelarut selulosa yang telah dikenal) (Puls, Janzon and Saake, 2006). Janzon, Puls and Saake, (2006) melakukan percobaan menggunakan nitren $7 \%$, diperoleh dissolving pulp dengan selulosa alfa $96 \%$ dan hemiselulosa 3,3\%. Modifikasi lain dilakukan oleh Puls, Janzon and Saake, (2006) yaitu kombinasi nitren 5\% dengan ekstraksi alkali $\mathrm{NaOH} 10 \%$ dan KOH 14\% sehingga diperoleh dissolving pulp dengan rata-rata kandungan selulosa alfa di atas 95\% dan hemiselulosa dibawah 4\%. Janzon et al. (2008) menyatakan bahwa struktur pulp yang diekstrak nitren mirip dengan dissolving pulp konvensional. Namun kelemahan metode pelarut kompleks logam adalah nikel dapat dengan mudah mencemari pulp yang diekstraksi, penggunaan senyawa nikel yang karsinogen dan bersifat alergi, serta kompleks logam yang digunakan hanya memiliki sedikit efek pada mannan sehingga membatasi untuk digunakan pada softwood (Roselli et al., 2014).

\section{d. Larutan Ionik}

Metode lainnya adalah ekstraksi menggunakan larutan ionik atau ionic liquor extraction (IONCELL), hemiselulosa diekstraksi oleh larutan ionik. Metode IONCELL mampu memisahkan pulp kertas menjadi fraksi selulosa dan fraksi hemiselulosa masing-masing pada kadar kemurnian tinggi (Froschauer et al., 2013). Larutan ionik adalah garam organik yang mengandung kation dan anion dengan titik leleh rendah (di bawah $100{ }^{\circ} \mathrm{C}$ ), tidak mudah menguap, tidak beracun, tidak mudah terbakar dan stabil secara termal dan kimia. Selulosa yang dilarutkan dalam larutan ionik dapat diregenerasi oleh anti-pelarut seperti air, etanol, dan aseton (Hermanutz et al., 2008; Li, 
2010). Larutan ionik dengan anion halida akan memiliki viskositas yang relatif tinggi sehingga menyulitkan saat proses pelarutan. Larutan ionik dengan anion seperti asetat, format dan fosfat akan memiliki viskositas rendah sehingga dapat digunakan untuk berbagai aplikasi. Larutan ionik yang umum digunakan secara komersial adalah 1-ethyl-3-methylimidazolium acetate (EMIM OAc) yang memiliki kemampuan melarutkan selulosa dengan baik (Isik, Sardon and Mecerreyes, 2014).

Laine et al. (2016) mengkonversi pulp kertas softwood menjadi dissolving pulp menggunakan larutan ionik EMIM OAc yang dicampurkan dengan air, diperoleh dissolving pulp dengan kandungan selulosa alfa $96,7 \%$, dan rendah hemiselulosa (1\%). Froschauer et al. (2013) melakukan kombinasi antara EMIM OAc) 15\% dengan CCE sehingga dihasilkan dissolving pulp dengan kandungan selulosa alfa 96,9\% dan hemiselulosa 3,1\%. Sedangkan Roselli et al. (2014) menunjukkan bahwa pulp asetat dengan kemurnian tinggi juga dapat diperoleh dari pulp Eucalyptus urograndis yang dikonversi melalui proses IONCELL, dimana kandungan hemiselulosa berhasil dikurangi dari awal 16,6\% menjadi $2,2 \%$, bahkan hingga $1,7 \%$ jika proses IONCELL dikombinasikan dengan enzim endoxilanase dosis $500 \mathrm{U}$. Kemudian selulosa asetat yang dihasilkan sebanding dengan selulosa asetat komersial. Hal-hal tersebut membuat proses IONCELL sebagai metode alternatif yang menarik.

\section{e. Mekanis}

Metode mekanis lebih sering digunakan sebagai pra-perlakuan bahan baku sebelum penggunaan bahan kimia ataupun enzim. Hasil penelitian menunjukkan bahwa perlakuan mekanis membuka struktur serat, meningkatkan luas permukaan serat, memperbanyak fraksi serat pendek, dan meningkatkan pembentukan pori mikro, lalu diikuti oleh ekstraksi rendah alkali sehingga proses penghilangan hemiselulosa lebih mudah dilakukan. Proses ini memungkinkan digunakannya alkali dengan konsentrasi rendah namun memiliki tingkat penghilangan hemiselulosa yang sama dengan proses konvensional, dan pulp yang dihasilkan dari metode kombinasi mekanis-alkali memiliki reaktivitas Fock yang tinggi (Duan, Verma, et al., 2015). Li et al. (2015) melakukan kombinasi
$\mathrm{CCE} \mathrm{NaOH} 4 \%$ dengan pra-perlakuan mekanis pulp pada alat PFI mill 10.000 revolution. Hasilnya hemiselulosa melalui pra-perlakuan mekanis lebih rendah (4,8\%) dibandingkan perlakuan CCE saja tanpa mekanis (7,8\%). Selain itu pra-perlakuan mekanis juga mampu meningkatkan reaktivitas dissolving pulp sebesar $43,8 \%$, dibandingkan dengan perlakuan tunggal CCE sebesar 39,5\%. Penelitian lain dilakukan Duan, Verma, et al. (2015a) menggunakan kombinasi PFI mill 3.000 revolution, CCE, dan enzim endoglukanase diperoleh dissolving pulp maple dengan kandungan hemiselulosa 4,46\% dan reaktivitas $81 \%$.

\section{Metode Enzim dan Kombinasi atara Enzim dan Metode Konvensional}

Enzim mampu menghilangkan hemiselulosa dan meningkatkan akses selulosa dalam dissolving pulp. Keunggulan enzim lainnya adalah kinerja tinggi, selektivitas tinggi pada substrat, dan lebih sedikit atau sama sekali tidak toksik dibandingkan dengan reagen kimia konvensional (Engstrom, Ek and Henriksson, 2006; Ibarra et al., 2010; Gehmayr and Sixta, 2012). Metode pembuatan dissolving pulp menggunakan enzim dianggap sebagai salah satu cara yang paling menjanjikan karena reaksi selektifnya terhadap hemiselulosa tanpa efek merugikan pada selulosa, tidak beracun dan lebih ramah lingkungan (Li et al., 2012; Zhao et al., 2017).

Kuatnya interaksi antara selulosa dan hemiselulosa serta tingkat lignifikasi menyebabkan lignoselulosa memiliki ketahanan tertentu terhadap enzim. Karena itu diperlukan kombinasi dengan pra-perlakuan mekanis ataupun kimia untuk mengatasi hambatan fisik pada dinding sel, kristalinitas selulosa, dan lignin, sehingga enzim dapat mengakses struktur makro. Proses pra-perlakuan akan mempengaruhi biaya di hilir melalui faktor pengurangan ukuran bahan, tingkat toksisitas fermentasi, tingkat hidrolisis enzim, pemuatan enzim, dan variabel proses lainnya (Zhao, Cheng and Liu, 2009). Pada pengolahan pulp kraft dengan pemberian xilanase, energi yang dibutuhkan untuk proses pemurnian mampu dikurangi serta menghasilkan kertas dengan sifat kekuatan yang lebih baik (Buzała et al., 2016). Penggunaan enzim xilanase sebelum proses pemutihan ECF dan TCF juga membantu dalam mengurangi konsumsi bahan kimia. Enzim xilanase membantu proses 
pemutihan dengan menghilangkan xilan dari kompleks lignin-karbohidrat, serta mencuci lignin yang terperangkap, dimana xilan yang dihilangkan hampir 50\%, terjadi peningkatan reaktivitas, dan berkurangnya hornifikasi serat (Gehmayr, Schild and Sixta, 2011). Penelitian lain menunjukkan bahwa dissolving pulp dari proses pemutihan xilanase memiliki kualitas lebih tinggi daripada pemutihan menggunakan oksigen sehingga memenuhi persyaratan spesifikasi SNI 0938:2010 (Sugesty, Kardiansyah and Pratiwi, 2015)

Metode ekstraksi alkali telah dikenal sebagai cara penghilangan hemiselulosa yang efektif (Janzon, Saake and Puls, 2008; Jarriault et al., 2014). Selanjutnya, kombinasi dari penggunaan enzim dan ekstraksi alkali menunjukkan efek sinergis pada penghilangan hemiselulosa (Ibarra, Kopcke and Ek, 2009; Gehmayr, Schild, and Sixta, 2011; Gehmayr and Sixta, 2012). Penelitian yang telah dilakukan oleh Köpcke, Ibarra and Ek, (2008); Ibarra, Kopcke and Ek, (2009); Ibarra et al. (2010); Köpcke, (2010); Li et al. (2012); Zhao, (2016) menggunakan kombinasi enzim dengan alkali berhasil meningkatkan reaktivitas selulosa pulp kertas. Enzim xilanase berperan sebagai katalis proses hidrolisis rantai panjang xilan menjadi rantai pendek. Selanjutnya xilanase bekerja menghilangkan xilan yang menghalangi endoglukanase untuk bereaksi mengikat selulosa dan membantu peningkatan reaktivitas (Ibarra et al., 2009; D. Li, Ibarra, et al., 2012). Kombinasi antara enzim dan alkali tidak hanya untuk menghilangkan hemiselulosa namun juga untuk memperbaiki sifat karakteristik pulp (Bajpai, 2014). Saat proses konversi pulp kertas, penambahan enzim mampu menghambat efek hornifikasi yang diakibatkan oleh proses alkali (Kopcke, Ibarra and Ek, 2008).

Pengurangan residu hemiselulosa hingga hilang total sulit terjadi karena adanya modifikasi substrat ataupun penghalang struktural. Pada pulp yang diputihkan, pentosan terlindung oleh komponen pulp lainnya sehingga tidak rentan terhadap serangan enzim, bahkan saat digunakan kadar enzim yang tinggi dan waktu inkubasi yang lama (Bajpai, 2014). Faktor lain yang dapat mempengaruhi sulitnya penghilangan xilan dari pulp adalah jenis spesies kayu, metode pembuatan pulp, aksesibilitas terhadap pentosan dan banyaknya pentosan dalam pulp, kemampuan penetrasi dan spesifisitas substrat enzim, penghambatan oleh bahan-bahan kimia proses pemutihan, serta ikatan kovalen dan hidrogen antara xilan ke lignin dan selulosa (Bajpai, 2018). Li et al. (2015) menyatakan bahwa hemiselulosa yang telah dipisahkan masih dapat digunakan dengan proses konversi menjadi produk lain seperti bio-etanol, furfural, dan xylitol .

\section{Karakteristik Dissolving Pulp}

Di Indonesia dissolving pulp sebagai bahan baku pembuatan serat rayon, memiliki spesifikasi sesuai standar SNI 938-2017. Parameter kualitas utama dissolving pulp adalah kandungan selulosa alfa yang tinggi ( $>90 \%)$ dan kandungan hemiselulosa yang rendah (2-6\%). Dissolving pulp yang dihasilkan dari proses asam sulfit mengandung $\alpha$-selulosa 92-94\%, sedangkan dari proses PHK sebesar 94-96\% (Duan, Li, et al., 2015; Bajpai, 2018). Kemurnian dissolving pulp dapat ditingkatkan melalui perlakuan proses mekanis, kimia atau enzimatik, dimana proses ini dapat diterapkan sendiri atau dalam multi-tahap (Chen et al., 2016). Pemurnian lanjutan dengan alkali tertentu diketahui mampu meningkatkan yield selulosa hingga 96\% untuk proses asam sulfit dan hingga 98\% untuk proses PHK (Bajpai, 2018). Dissolving pulp dengan kemurnian tinggi, akan menentukan viskositas (Tian et al., 2014). Viskositas pulp merupakan salah satu parameter kendali setelah proses pemutihan untuk melihat sampai sejauh mana selulosa terdegradasi. Penentuan viskositas dapat diekspresikan dalam centipoises ( $\mathrm{cP}$ ) atau milipascalsecond (mPas) dan viskositas intrinsik dengan satuan milliliter per gram $(\mathrm{mL} / \mathrm{g})$ (Henriksson, Christiernin and Agnemo, 2005); (Kvarnlof N. et al., 2006). Viskositas intrinsik yang diharapkan dari dissolving pulp berada dalam kisaran 400 hingga $600 \mathrm{~mL} \mathrm{~g}^{-1}$, dan akan direduksi menjadi 200 hingga $250 \mathrm{~mL} \mathrm{~g}^{-1}$ saat proses ageing saat pembuatan viskosa rayon (Duan, Li, et al., 2015). Viskositas intrinsik yang terlalu rendah menyebabkan pemekaran larutan viskosa menjadi seperti gel, menyulitkan proses filtrasi dan mengurangi kekuatan fisik serat rayon; sementara viskositas intrinsik yang terlalu tinggi menyebabkan larutan tidak homogen saat merserisasi dan xantasi (Tian et al., 2013).

Parameter reaktivitas dissolving pulp umumnya diukur dengan menggunakan metode uji Fock, yang lebih mudah diaplikasikan di laboratorium. Tingginya reaktivitas selulosa akan meningkatkan homogenitas dan kualitas 
Tabel 4. Karakteristik Dissolving Pulp beberapa Jenis Nonkayu dan Kayu

\begin{tabular}{|c|c|c|c|c|c|c|c|c|c|c|c|c|}
\hline $\begin{array}{l}\text { Parameter proses } \\
\text { (Process } \\
\text { parameter) }\end{array}$ & $\begin{array}{l}\text { Bagas }^{1} \\
\left(\mathrm{Ba}^{-}\right. \\
\text {gasse })\end{array}$ & $\begin{array}{l}\text { Jerami } \\
\text { padi }^{2} \\
\text { (Rice } \\
\text { straw) }\end{array}$ & $\begin{array}{c}\text { Batang } \\
\text { pisang }^{3} \\
\text { (Banana } \\
\text { plant stem) }\end{array}$ & $\begin{array}{c}\text { Bambu } \\
\text { hijau }^{4} \\
(\text { Green } \\
\text { bamboo })\end{array}$ & $\begin{array}{c}\text { Bambu } \\
\text { duri }{ }^{5} \\
\text { (Spiny } \\
\text { bamboo) }\end{array}$ & $\begin{array}{l}\text { Bambu } \\
\text { mayan }^{6} \\
\text { (Mayan } \\
\text { bamboo) }\end{array}$ & $\begin{array}{c}\text { Bambu } \\
\text { sembil- } \\
\text { ang }^{6} \\
\text { (Sem- } \\
\text { bilang } \\
\text { bamboo) }\end{array}$ & $\begin{array}{l}\text { Kenaf }^{7} \\
\text { (Kenaf) }\end{array}$ & $\begin{array}{l}\text { Jute }^{8} \\
\text { (Jute) }\end{array}$ & $\begin{array}{c}\text { Acacia } \\
\text { mangi- } \\
\text { um }^{9}\end{array}$ & $\begin{array}{l}\text { Acacia } \\
\text { crassi- } \\
\text { carpa }^{10}\end{array}$ & $\begin{array}{c}\text { Eucalyptus } \\
\text { urogran- } \\
\text { dis }^{11}\end{array}$ \\
\hline $\begin{array}{l}\text { Selulosa alfa } \\
\text { (Alpha cellulose, } \\
\%)\end{array}$ & $\begin{array}{l}91,30- \\
91,80\end{array}$ & 86,80 & $\begin{array}{l}90,70- \\
94,20\end{array}$ & 97,60 & $\begin{array}{l}94,88- \\
98,67\end{array}$ & 96,57 & $\begin{array}{l}96,61- \\
97,49\end{array}$ & $\begin{array}{l}86,36- \\
86,71\end{array}$ & $\begin{array}{l}91,00- \\
92,40\end{array}$ & $\begin{array}{c}88,00- \\
91,06\end{array}$ & $\begin{array}{l}91,85- \\
94,13\end{array}$ & $\begin{array}{c}95,40- \\
97,70\end{array}$ \\
\hline $\begin{array}{l}\text { Pentosan } \\
\text { (Pentosan, \%) }\end{array}$ & $\begin{array}{c}4,60- \\
4,70\end{array}$ & - & $1,50-3,70$ & 1,80 & - & - & - & $\begin{array}{l}14,71- \\
14,97\end{array}$ & $\begin{array}{c}6,50- \\
6,70\end{array}$ & $\begin{array}{l}1,13- \\
2,05\end{array}$ & $\begin{array}{c}0,65- \\
1,47\end{array}$ & $1,50-3,90$ \\
\hline $\begin{array}{l}\text { Kelarutan dalam } \\
\text { alkali } 18 \% \\
\text { (Solubility in } \\
\text { alkali } 18 \%, \% \text { ) }\end{array}$ & - & - & - & - & $\begin{array}{l}3,57- \\
4,07\end{array}$ & 1,29 & $\begin{array}{l}1,20- \\
1,32\end{array}$ & $\begin{array}{l}7,33- \\
7,65\end{array}$ & $\begin{array}{l}7,08- \\
7,52\end{array}$ & $\begin{array}{l}1,29- \\
1,60\end{array}$ & $\begin{array}{c}1,29- \\
1,67\end{array}$ & $2,30-4,20$ \\
\hline $\begin{array}{l}\text { Kelarutan dalam } \\
\text { alkali } 10 \% \\
\text { (Solubility in } \\
\text { alkali } 10 \%, \% \text { ) }\end{array}$ & - & - & - & - & $\begin{array}{l}6,22- \\
6,64\end{array}$ & 4,69 & $\begin{array}{c}4,29- \\
5,04\end{array}$ & $\begin{array}{l}10,34- \\
10,93\end{array}$ & $\begin{array}{l}10,80- \\
13,00\end{array}$ & $\begin{array}{l}4,67- \\
5,68\end{array}$ & $\begin{array}{l}3,48- \\
4,76\end{array}$ & $2,30-5,00$ \\
\hline $\begin{array}{l}\text { Derajat cerah } \\
\text { (Brightness, } \\
\% I S O \text { ) }\end{array}$ & $\begin{array}{l}88,10- \\
88,50\end{array}$ & 88,00 & $\begin{array}{l}72,60- \\
82,30\end{array}$ & 73,20 & $\begin{array}{l}85,38- \\
89,61\end{array}$ & 87,26 & $\begin{array}{l}87,63- \\
88,12\end{array}$ & $\begin{array}{l}86,23- \\
86,27\end{array}$ & $\begin{array}{l}88,33- \\
88,60\end{array}$ & $\begin{array}{l}86,24- \\
86,32\end{array}$ & $\begin{array}{c}88,80- \\
89,70\end{array}$ & $\begin{array}{l}89,40- \\
90,40\end{array}$ \\
\hline $\begin{array}{l}\text { Viskositas } \\
\text { (Viscosity, } c P \text { ) }\end{array}$ & - & - & $5-23$ & - & $\begin{array}{l}16,43- \\
25,75\end{array}$ & 16,21 & $\begin{array}{l}15,97- \\
17,03\end{array}$ & $\begin{array}{l}27,55- \\
29,06\end{array}$ & $\begin{array}{l}3,05- \\
3,54\end{array}$ & $\begin{array}{l}5,18- \\
5,82\end{array}$ & $\begin{array}{l}7,18- \\
9,19\end{array}$ & $481-750$ \\
\hline $\begin{array}{l}\text { Viskositas } \\
\text { instrinsik } \\
\text { (Instrinsic } \\
\text { viscosity, } \mathrm{mL} / \mathrm{g} \text { ) }\end{array}$ & $\begin{array}{l}270- \\
295\end{array}$ & - & - & 927 & $553-731$ & 556 & $560-567$ & - & - & - & - & - \\
\hline
\end{tabular}

produk akhir derivat selulosa, serta mengurangi kebutuhan penggunaan reaktan dalam proses pembuatannya (Ibarra, Kopcke and Ek, 2010). Parameter keseragaman distribusi berat molekul (MWD) adalah hal penting lain agar proses merserisasi dan xantasi homogen saat pembuatan viskosa, sehingga diperoleh produk akhir rayon yang baik (Sixta, 2006; Duan, Li, et al., 2015a). Umumnya pulp dari proses asam sulfit memiliki MWD yang agak lebar dan indeks polidispersitas tinggi (PDI) $(7,6-8,5)$ sedangkan pulp dari proses PHK menunjukkan MWD yang lebih sempit dan seragam, serta PDI yang lebih rendah (3,8-4,5) (Duan, Li, et al., 2015). Pulp dengan MWD yang lebar akan memberi dampak yang tidak diinginkan dalam hal kemampuan proses dan sifat produk derivat selulosa yang dihasilkan (Chen et al., 2016). Parameter khusus lainnya meliputi kelarutan alkali, derajat polimerisasi (DP), kecerahan (Chen et al., 2016; Zhao et al., 2017).

Kandungan selulosa alfa dissolving pulp nonkayu pada Tabel 4 menunjukkan sebagian besar lebih dari $90 \%$, hanya jerami padi dan kenaf yang tidak mencapai $90 \%$. Hemiselulosa merupakan pengotor yang tidak diharapkan dalam dissolving pulp, karena akan mempengaruhi proses selanjutnya setelah menjadi produk. Kelarutan dalam alkali merupakan parameter untuk mengevaluasi komposisi karbohidrat dalam pulp yang dapat mencerminkan kandungan selulosa alfa dan selulosa yang larut dalam larutan alkali. Kelarutan paling tingi adalah dalam larutan natrium hidroksida $10 \%$. Bahan baku nonkayu cukup menjanjikan sebagai baku untuk dissolving pulp, jika melihat karakteristik yang dihasilkan. Apabila dibandingkan dengan dissolving pulp dari kayu, karakteristik dissolving pulp dari bahan baku nonkayu cukup kompetitif. Sehingga dapat digunakan sebagai sumber bahan baku alternatif selain kayu.

\section{Kesimpulan}

Bahan baku nonkayu memiliki potensi sebagai bahan baku dissolving pulp seperti bagas, batang pisang, bambu dan jute. Proses pembuatan dissolving pulp dari kayu menggunakan proses prahidrolisis kraft, sedangkan dari nonkayu dapat menggunakan proses prahidrolisis kraft atau proses prahidrolisis soda. Proses prahidrolisis secara umum dapat menggunakan air atau asam encer. Dissolving pulp dari bagas, batang pisang, bambu dan jute memiliki kandungan selulosa alfa di atas $90 \%$, sehingga dapat dipertimbangkan sebagai bahan baku alternatif selain kayu. Selain pembuatan dissolving pulp dengan proses prahidrolisis kraft atau proses prahidrolisis 
soda, terdapat metode alternatif lain yang lebih ramah lingkungan dan relatif murah serta dapat dikembangkan yaitu konversi pulp kertas menjadi dissolving pulp. Berbagai metode konversi pulp kertas yang tersedia seperti proses enzim dan larutan ionik memiliki sejumlah potensi yang menarik, namun juga perlu diperhatikan kekurangan yang menyertainya. Pada akhirnya pemilihan jenis bahan baku dan kesesuaian dengan metode pengolahannya akan menentukan sifat dan karakteristik produk akhir derivat selulosa yang diharapkan.

\section{Daftar Pustaka}

Alvarez, R. S. and Tjeerdsma, B. F. (1995) 'Organosolv Pulping of Poplar Wood from Short-Rotation Intensive Culture Plantations', Wood and Fiber Science, 27(4), pp. 395-401.

Andrade, M. F. and Colodette, J. L. (2014) 'Dissolving Pulp Production from Sugar Cane Bagasse', Industrial Crops and Products, 52, pp. 58-64. doi: 10.1016/j. indcrop.2013.09.041.

Awano, T., Takabe, K. and Fujita, M. (2001) Xylan and Lignin Deposition on The Secondary Wall of Fagus Crenata Fibers, Molecular Breeding of Woody Plants. Elsevier Masson SAS. doi: 10.1016/S09210423(01)80065-4.

Bajpai, P. (2014) Xylanolytic Enzymes, Elsevier Inc. doi: 10.1016/C2013-0-18577-7.

Bajpai, P. (2018) Biotechnology for Pulp and Paper Processing, Springer Science+Business Media. doi: 10.1007/978981-10-7853-8.

Behin, J. and Zeyghami, M. (2009) 'Dissolving Pulp from Corn Stalk Residue and Waste Water of Merox Unit', Chemical Engineering Journal, 152(1), pp. 26-35. doi: 10.1016/j. cej.2009.03.024.

Biermann, C. J. (1996) Handbook of Pulping and Papermaking. 2nd ed. Academic Press. doi: 10.1016/B978-0-12-097362-0.X5000-6.

Buzała, K. P., Przybysz, P., Kalinowska, H. and Derkowska, M. (2016) 'Effect of Cellulases and Xylanases on Refining Process and Kraft Pulp Properties', Plos One, pp. 1-14. doi: 10.1371/journal.pone.0161575.

Cao, S., Ma, X., Lin, L., Huang, F., Huang, L. and Chen, L. (2014) 'Morphological and Chemical Characterization of Green Bamboo (Dendrocalamopsis oldhami (Munro) Keng f.) for Dissolving Pulp Production', BioResources, 9(3), pp. 4528-4539. doi: 10.15376/biores.9.3.4528-4539.
Chen, C., Duan, C., Li, J., Liu, Y., Ma, X., Zheng, L., Stavik, J. and Ni, Y. (2016) 'Cellulose (Dissolving Pulp) Manufacturing Processes and Properties: A Mini-Review', BioResources, 11(2), pp. 1-12.

Christov, L. P., Akhtar, M. and Prior, B. A. (1998) 'The Potential of Biosulfite Pulping in Dissolving Pulp Production', Enzyme and Microbial Technology, 23(1-2), pp. 70-74. doi: 10.1016/S0141-0229(98)00017-9.

Christov, L. P. and Prior, B. A. (1993) 'Xylan Removal from Dissolving Pulp Using Enzymes of Aureobasidium pullulans', Biotechnology Letters, 15(12), pp. 12691274. doi: 10.1007/BF00130310.

Das, A. K., Nakagawa-Izumi, A. and Ohi, H. (2016) 'Quality Evaluation of Dissolving Pulp Fabricated from Banana Plant Stem and Its Potential for Biorefinery', Carbohydrate Polymers. Elsevier Ltd., 147, pp. 133-138. doi: 10.1016/j.carbpol.2016.03.103.

Desch, H. E. and Dinwoodie, J. M. (1996) Timber Structure, Properties, Conversion and Use, MacMillan Press Ltd.

Dien, L. Q., Cuong, T. D., Hoang, P. H., Hoa, D. T. and Thanh, L. T. (2015) 'Production of Dissolving Cellulose from Rice Straw in Vietnam by Pre-hydrolysis Kraft Pulping', 1(3), pp. 359-365.

Duan, C., Li, J., Ma, X., Chen, C., Liu, Y., Stavik, J. and Ni, Y. (2015) 'Comparison of Acid Sulfite (AS ) - and Prehydrolysis Kraft ( PHK ) -Based Dissolving Pulps', Cellulose. Springer Netherlands. doi: 10.1007/s10570-015-0781-1.

Duan, C., Long, Y., Li, J., Ma, X. and Ni, Y. (2015) 'Changes of Cellulose Accessibility to Cellulase Due To Fiber Hornification and Its Impact on Enzymatic Viscosity Control of Dissolving Pulp', Cellulose. Springer Netherlands, 22(4), pp. 2729-2736. doi: 10.1007/s10570-015-0636-9.

Duan, C., Verma, S. K., Li, J., Ma, X. and Ni, Y. (2015) 'Combination of Mechanical, Alkaline and Enzymatic Treatments to Upgrade Paper-Grade Pulp to Dissolving Pulp with High Reactivity', Bioresource Technology. Elsevier Ltd. doi: 10.1016/j. biortech.2015.10.067.

Ek, M., Gellerstedt, G. and Henriksson, G. (2009) Wood Chemistry and Biotechnology, De Gruyter $\mathrm{GmbH} \&$ Co. doi: 10.1515/9783110213409.

Engstrom, A.-C., Ek, M. and Henriksson, G. (2006) 'Improved Accessibility and Reactivity of Dissolving Pulp for the Viscose Process : Pretreatment with Monocomponent Endoglucanase', Biomacromolecules, 7, pp. 2027-2031. doi: 10.1021/bm0509725. 
Fatehi, P. and Ni, Y. (2011) 'Integrated Forest Biorefinery-Prehydrolysis/Dissolving Pulping Process', ACS Symposium Series, pp. 475-506. doi: 10.1021/bk-2011-1067.ch018.

Froschauer, C., Hummel, M., Iakovlev, M., Roselli, A., Schottenberger, H. and Sixta, H. (2013) 'Separation of Hemicellulose and Cellulose from Wood Pulp by Means of Ionic Liquid/ Cosolvent Systems', Biomacromolecules. doi: 10.1021/bm400106h.

Gehmayr, V., Potthast, A. and Sixta, H. (2012) 'Reactivity of Dissolving Pulps Modified by TEMPO-Mediated Oxidation', Cellulose, 19, pp. 1125-1134. doi: 10.1007/s10570-0129729-x.

Gehmayr, V., Schild, G. and Sixta, H. (2011) 'A Precise Study on The Feasibility of Enzyme Treatments of A Kraft Pulp for Viscose Application', Cellulose, 18, pp. 479-491. doi: 10.1007/s10570-010-9483-x.

Gehmayr, V. and Sixta, H. (2011) 'Dissolving Pulps from Enzyme Treated Kraft Pulps for Viscose Application', Lenzinger Berichte, 89, pp. 152160.

Gehmayr, V. and Sixta, H. (2012) 'Pulp Properties and Their Influence on Enzymatic Degradability', Biomacromolecules, 13, pp. 645-651. doi: $10.1021 / \mathrm{bm} 201784 \mathrm{u}$.

Hämmerle, F. M. (2011) 'The Cellulose Gap (The Future of Cellulose Fibres)', Lenzinger Berichte, 89, pp. 12-21.

Henriksson, G., Christiernin, M. and Agnemo, R. (2005) 'Monocomponent Endoglucanase Treatment Increases the Reactivity of Softwood Sulphite Dissolving Pulp', Journal of Industrial Microbiology and Biotechnology, 32, pp. 211214. doi: 10.1007/s10295-005-0220-7.

Hermanutz, F., Gahr, F., Uerdingen, E., Meister, F. and Kosan, B. (2008) 'New Developments in Dissolving and Processing of Cellulose in Ionic Liquids', Macromol. Symp., 262, pp. 23-27. doi: 10.1002/masy.200850203.

Hon, D. N. S. and Shiraishi, N. (2001) Wood and Cellulosic Chemistry, Revised, and Expanded, Marcel Dekker, Inc. doi: 10.1201/9781482269741.

Ibarra, D., Kopcke, V. and Ek, M. (2009) 'Exploring Enzymatic Treatments for The Production of Dissolving Grade Pulp from Different Wood and Non-Wood Paper Grade Pulps', Holzforschung, 63, pp. 721-730. doi: 10.1515/HF.2009.102.

Ibarra, D., Kopcke, V. and Ek, M. (2010) 'Behavior of Different Monocomponent Endoglucanases on The Accessibility and Reactivity of Dissolving-Grade Pulps for Viscose Process', Enzyme and Microbial Technology. Elsevier Inc., 47(7), pp. 355-362. doi: 10.1016/j. enzmictec.2010.07.016.
Ibarra, D., Kopcke, V., Tomas, P., Jääskeläinen, A. and Ek, M. (2010) 'Combination of Alkaline and Enzymatic Treatments as A Process for Upgrading Sisal Paper-Grade Pulp to DissolvingGrade Pulp', Bioresource Technology. Elsevier Ltd, 101(19), pp. 7416-7423. doi: 10.1016/j. biortech.2010.04.050.

Isik, M., Sardon, H. and Mecerreyes, D. (2014) 'Ionic Liquids and Cellulose: Dissolution, Chemical Modification and Preparation of New Cellulosic Materials', International Journal of Molecular Sciences, 15, pp. 11922-11940. doi: 10.3390/ ijms150711922.

Istikowati, W. T., Aiso, H., Sunardi, S., Sutiya, B., Ishiguri, F., Ohshima, J., lizuka, K. and Yokota, S. (2016) 'Wood, Chemical, and Pulp Properties of Woods from Less-Utilized Fast-Growing Tree Species Found in Naturally Regenerated Secondary Forest in South Kalimantan, Indonesia', Journal of Wood Chemistry and Technology, 36(4), pp. 250-258. doi: 10.1080/02773813.2015.1124121.

Jahan, M. S., Ahsan, L., Noori, A. and Quaiyyum, M. A. (2008) 'Process for The Production of Dissolving Pulp from Trema orientalis (Nalita) by Prehydrolysis Kraft and Soda-Ethylenediamine (EDA) Process', BioResources, 3(3), pp. 816828.

Janzon, R., Puls, J., Bohn, A., Potthast, A. and Saake, B. (2008) 'Upgrading of Paper Grade Pulps to Dissolving Pulps by Nitren Extraction: Yields , Molecular and Supramolecular Structures of Nitren Extracted Pulps', Cellulose, 15, pp. 739 750. doi: 10.1007/s10570-008-9224-6.

Janzon, R., Puls, J. and Saake, B. (2006) 'Upgrading of Paper-Grade Pulps to Dissolving Pulps by Nitren Extraction: Optimisation of Extraction Parameters and Application to Different Pulps', Holzforschung, 60(1997), pp. 347-354. doi: 10.1515/HF.2006.055.

Janzon, R., Saake, B. and Puls, J. (2008) 'Upgrading of Paper-Grade Pulps to Dissolving Pulps by Nitren Extraction : Properties of Nitren Extracted Xylans in Comparison to $\mathrm{NaOH}$ and $\mathrm{KOH}$ Extracted Xylans', Cellulose, 15, pp. 161-175. doi: 10.1007/s10570-007-9154-8.

Jarriault, B. A., Lachenal, D., Chirat, C. and Heux, L. (2014) 'Upgrading Softwood Bleached Kraft Pulp to Dissolving Pulp by Cold Caustic Treatment and Acid-Hot Caustic Treatment', Industrial Crops \& Products. Elsevier B.V., pp. 1-7. doi: 10.1016/j.indcrop.2014.09.051.

Kaur, P., Bhardwaj, N. K. and Sharma, J. (2016) 'Pretreatment with Xylanase and Its Significance inHemicellulose Removal from MixedHardwood Kraft Pulp as A Process Step for Viscose', Carbohydrate Polymers. Elsevier Ltd., 145, pp. 95-102. doi: 10.1016/j.carbpol.2016.03.023. 
Kopcke, V. (2010) Conversion of Wood and Non-wood Paper-grade Pulps to Dissolvinggrade Pulps, Doctoral Thesis. Royal Institute of Technology Sweden.

Kopcke, V., Ibarra, D. and Ek, M. (2008) 'Increasing Accessibility and Reactivity of Paper Grade Pulp by Enzymatic Treatment for Use as Dissolving Pulp', Nordic Pulp and Paper Research Journal, 23(4), pp. 363-368. doi: 10.3183/NPPRJ-2008-23-04-p363-368.

Kvarnlof N., Germgard, U., Jonsson, L. J. and Soderlund, C. A. (2006) 'Enzymatic Treatment to Increase The Reactivity of A Dissolving Pulp for Viscose Preparation', Appita Journal, 59(3), pp. 242-246.

Laine, C., Asikainen, S., Talja, R., Stépán, A., Sixta, H. and Harlin, A. (2016) 'Simultaneous Bench Scale Production of Dissolving Grade Pulp and Valuable Hemicelluloses from Softwood Kraft Pulp by Ionic Liquid Extraction', Carbohydrate Polymers. Elsevier Ltd., 136, pp. 402-408. doi: 10.1016/j.carbpol.2015.09.039.

Li, D. (2010) Evaluation of Ionic Liquids as Direct Solvents for the Manufacturing of Novel Products from Cellulose, Master of Science Thesis. Chalmers University of Technology.

Li, D., Ibarra, D., Kopcke, V. and Ek, M. (2012) 'Production of Dissolving Grade Pulps from Wood and Non-Wood Paper-Grade Pulps by Enzymatic and Chemical Pretreatments', ACS Symposium Series. doi: 10.1021/bk2012-1107.ch009.

Li, D., Sevastyanova, O. and Ek, M. (2012) 'Pretreatment of Softwood Dissolving Pulp with Ionic Liquids', Holzforschung, 66, pp. 935-943. doi: 10.1515/hf-2011-0180.

Li, J., Liu, Y., Duan, C., Zhang, H. and Ni, Y. (2015) 'Mechanical Pretreatment Improving Hemicelluloses Removal from Cellulosic Fibers During Cold Caustic Extraction', Bioresource Technology. Elsevier Ltd, 192, pp. 501-506. doi: 10.1016/j. biortech.2015.06.011.

Liu, X., Fatehi, P. and Ni, Y. (2011) 'Adsorption of Lignocelluloses Dissolved in Prehydrolysis Liquor of Kraft-Based Dissolving Pulp Process on Oxidized Activated Carbons', Ind. Eng. Chem. Res., 50, pp. 11706-11711. doi: 10.1021/ie201036q.

Luo, X., Liu, J., Wang, H., Huang, L. and Chen, L. (2014) 'Comparison of HotWater Extraction and Steam Treatment for Production of High Purity-Grade Dissolving Pulp from Green Bamboo', Cellulose, 21(3), pp. 1445-1457. doi: 10.1007/s10570-0140234-2.
Martino, D. C., Colodette, J. L., Chandra, R. and Saddler, J. (2017) 'Steam Explosion Pretreatment Used to Remove Hemicellulose to Enhance The Production of A Eucalyptus Organosolv Dissolving Pulp', Wood Science and Technology. Springer Berlin Heidelberg, 51(3), pp. 557-569. doi: 10.1007/s00226016-0889-y.

Matin, M., Rahaman, M. M., Nayeem, J., Sarkar, M. and Jahan, M. S. (2015) 'Dissolving Pulp from Jute Stick', Carbohydrate Polymers. Elsevier Ltd., 115, pp. 44-48. doi: 10.1016/j. carbpol.2014.08.090.

Miao, Q., Chen, L., Huang, L., Tian, C., Zheng, L. and Ni, Y. (2014) 'A Process for Enhancing the Accessibility and Reactivity of Hardwood Kraft-Based Dissolving Pulp for Viscose Rayon Production by Cellulase Treatment', Bioresource Technology. Elsevier Ltd, 154, pp. 109-113. doi: 10.1016/j. biortech.2013.12.040.

Muurinen, E. (2000) Organosolv Pulping. A Review and Distillation Study Related to Peroxyacid Pulping, Academic Dissertation. University of Oulu, Finland. Available at: http://herkules.oulu.fi/issn03553213/.

Puls, J., Janzon, R. and Saake, B. (2006) 'Comparative Removal of Hemicelluloses from Paper Pulps Using Nitren, Cuen, $\mathrm{NaOH}$, and $\mathrm{KOH}^{\prime}$, Lenzinger Berichte, 86, pp. 63-70.

Purwita, C. A. and Sugesty, S. (2017) 'Dissolving Pulp Production from Spiny Bamboo (Bambusa blumeana)', Proceedings of International Workshop on Non-Wood Pulping and Papermaking Technology, pp. 207-216.

Purwita, C. A. and Sugesty, S. (2018) 'Pembuatan dan Karakterisasi Dissolving Pulp Serat Panjang dari Bambu Duri (Bambusa blumeana)', Jurnal Selulosa, 8(1), pp. 21-32. doi: 10.25269/jsel.v8i01.232.

Reddy, N. and Yang, Y. (2005) 'Biofibers from Agricultural Byproducts for Industrial Applications', Trends in Biotechnology, 23(1), pp. 22-27. doi: 10.1016/j. tibtech.2004.11.002.

Rodríguez, A., Serrano, L., Moral, A., Pérez, A. and Jiménez, L. (2008) 'Use of HighBoiling Point Organic Solvents for Pulping Oil Palm Empty Fruit Bunches', Bioresource Technology, 99(6), pp. 1743-1749. doi: 10.1016/j.biortech.2007.03.050.

Roselli, A., Hummel, M., Monshizadeh, A., Maloney, T. and Sixta, H. (2014) 'Ionic Liquid Extraction Method for Upgrading Eucalyptus Kraft Pulp to High Purity Dissolving Pulp', Cellulose. doi: 10.1007/s10570-014-0344-X. 
Saka, S. and Matsumura, H. (2004) 'Wood Pulp Manufacturing and Quality Characteristics', Macromol. Symp., 208, pp. 37-48. doi: 10.1002/masy.200450404.

Schaechter, M. (2009) Encyclopedia of Microbiology, Academic Press.

Schild, G. and Sixta, H. (2011) 'Sulfur-Free Dissolving Pulps and Their Application for Viscose and Lyocell', Cellulose, 18, pp. 1113-1128. doi: 10.1007/s10570-011-95320.

Sixta, H. (2006) Handbook of Pulp, Wiley - VCH. doi: 10.1002/9783527619887.

Sixta, H., Harms, H., Dapia, S., Parajo, J. C., Puls, J., Saake, B., Fink, H. P. and Roder, T. (2004) 'Evaluation of New Organosolv Dissolving Pulps . Part I: Preparation , Analytical Characterization and Viscose Processability', Cellulose, 11, pp. 73-83. doi: 10.1023/B:CE LL.0000014767.47330.90.

Sixta, H., Iakovlev, M., Testova, L., Roselli, A., Hummel, M., Borrega, M., Heiningen, A. van, Froschauer, C. and Schottenberger, H. (2013) 'Novel Concepts of Dissolving Pulp Production', Cellulose, 20, pp. 1547-1561. doi: 10.1007/s10570-013-9943-1.

Sugesty, S., Kardiansyah, T. and Hardiani, H. (2015) 'Bamboo as Raw Materials for Dissolving Pulp with Environmental Friendly Technology for Rayon Fiber', Procedia Chemistry. Elsevier Ltd., 17, pp. 194-199. doi: 10.1016/j.proche.2015.12.122.

Sugesty, S., Kardiansyah, T. and Pratiwi, W. (2015) 'Penggunaan Xilanase pada Pemutihan Dissolving Pulp Acacia crassicarpa', Jurnal Selulosa, 4(2), pp. 99-106. doi: 10.25269/ jsel.v2i01.27.

Sugesty, S. and Setiawan, Y. (2012) 'Making of Dissolving Pulp by Bio-Bleaching Process from Acacia mangium Wood', Proceeding The International Conference on the Innovation in Polymer Science and Technology, pp. 88-93.

Sugesty, S. and Setiawan, Y. (2013) 'Dissolving Pulp from Kenaf by Bio-Bleaching Process', Jurnal Selulosa, 3(2), pp. 81-88.

Tian, C., Zheng, L., Miao, Q., Cao, C. and Ni, Y. (2014) 'Improving the Reactivity of KraftBased Dissolving Pulp for Viscose Rayon Production by Mechanical Treatments', Cellulose. doi: 10.1007/s10570-014-0332-1.
Tian, C., Zheng, L., Miao, Q., Nash, C., Cao, C. and Ni, Y. (2013) 'Improvement in The Fock Test for Determining The Reactivity of Dissolving Pulp', Tappi Journal, 12(11), pp. 21-26.

Ververis, C., Georghiou, K., Christodoulakis, N., Santas, P. and Santas, R. (2004) 'Fiber Dimensions, Lignin and Cellulose Content of Various Plant Materials and Their Suitability for Paper Production', Industrial Crops and Products, 19(3), pp. 245-254. doi: 10.1016/j. indcrop.2003.10.006.

Vila, C., Santos, V. and Parajo, J. C. (2004) 'Dissolving Pulp from TCF Bleached Acetosolv Beech Pulp', Journal of Chemical Technology and Biotechnology, 79, pp. 1098-1104. doi: 10.1002/jctb.1090.

Wang, H., Pang, B., Wu, K., Kong, F., Li, B. and Mu, X. (2014) 'Two Stages of Treatments for Upgrading Bleached Softwood Paper Grade Pulp to Dissolving Pulp for Viscose Production', Biochemical Engineering Journal. Elsevier B.V., 82, pp. 183-187. doi: 10.1016/j.bej.2013.11.019.

Wang, N. and Chen, H. Z. (2013) 'Manufacture of Dissolving Pulps from Cornstalk by Novel Method Coupling Steam Explosion and Mechanical Carding Fractionation', Bioresource Technology. Elsevier Ltd, 139, pp. 59-65. doi: 10.1016/j. biortech.2013.04.015.

Woodings, C.(2001)RegeneratedCelluloseFibres, Woodhead Publishing Ltd and CRC Press LLC. Woodhead Publishing Ltd and CRC Press LLC. doi: 10.1533/9781855737587.

Zhao, L. (2016) Xylan Removal by Xylanase for the Production of Dissolving Pulp from Bamboo. The University of British Columbia. doi: 10.14288/1.0340669.

Zhao, L., Yuan, Z., Sella, N., Feng, X., Beatson, R., Trajano, H. L. and Martinez, D. M. (2017) 'Increasing Efficiency of Enzymatic Hemicellulose Removal from Bamboo for Production of High-Grade Dissolving Pulp', Bioresource Technology. Elsevier Ltd, 223, pp. 40-46. doi: 10.1016/j. biortech.2016.10.034.

Zhao, X., Cheng, K. and Liu, D. (2009) 'Organosolv Pretreatment of Lignocellulosic Biomass for Enzymatic Hydrolysis', Applied Microbiology Biotechnology, 82, pp. 815827. doi: 10.1007/s00253-009-1883-1. 
Jurnal Selulosa, Vol. 10, No. 1, Juni 2020:35-50

- Halaman ini sengaja dikosongkan - 